\title{
EFISIENSI PENGGUNAAN DIMENSI BALOK WIDE FLANGE (WF) TERHADAP KEKAKUAN STRUKTUR GEDUNG BPJN ACEH DENGAN PENAMBAHAN ELEMEN SHEAR WALL
}

\author{
Fakhrul Razi1 ${ }^{1, \mathrm{c})}$, Yulia Hayati ${ }^{2, \mathrm{a})}$, Teuku Budi Aulia ${ }^{2, \mathrm{~b})}$
}

${ }^{1}$ Mahasiswa Magister Teknik Sipil, Fakultas Teknik, Universitas Syiah Kuala

${ }^{2}$ Dosen Magister Teknik Sipil, Fakultas Teknik, Universitas Syiah Kuala

aCCorresponding author: yuliahayati@unsyiah.ac.id ${ }^{\mathrm{b}}$ aulia@gmail.com ${ }^{\mathrm{c}}$ ajie.indogunta@gmail.com

\begin{tabular}{l}
\hline INFO ARTIKEL \\
\hline Diterima \\
8 Juni 2021 \\
Direvisi \\
14 juni 2021 \\
Disetujui \\
21 Juni 2021
\end{tabular}

Keywords: steel structure; shearwall, SAP 2000; and earthquakes \begin{abstract}
The effect of earthquakes on the behavior of building structures such as houses, hotels, hospitals, offices and others is very high. Earthquakes can certainly cause economic losses and can result in human fatalities. The higher a building is, the use of skeletal structures to withstand lateral forces due to earthquake load becomes less economical because it will cause the dimensions of column and beam structures to be larger and the number of reinforcements required will also be moreandmore. The main office building has 2 (two) elliptical circular towers on the ground floor built using reinforced concrete material, while on the 1st floor (one) until the roof floor is built using steel material. For analisis earthquake force using earthquake data in banda aceh area, the calculation of loading is used inaccordance with the data obtained from planning consultants. Another factor being reviewed is the displacement and style of the building before and after the shear wall is added to the central structure of the building. Analyze the structure using a licensed SAP 2000 program. The steel structure research itself uses SNI 1729 - 2015 regulation on Steel Structure Planning Procedures for Building Buildings that adopt Load and Resistance Factor Design (LRFD) regulations. The expected result in this study is to analyze the strengthening of more economical building structures with the addition of shearwall elements between steel structures in the analyzed buildings as well as a review of the combination of loads and evaluate their rigidity
\end{abstract}

$\begin{array}{ll}\text { How to cite: } & \text { Razi Fakhrul, dkk (2021) Efisiensi Penggunaan Dimensi Balok Wide Flange (Wf) Terhadap } \\ & \text { Kekakuan Struktur Gedung Bpjn Aceh Dengan Penambahan Elemen Shear Wall. Jurnal Syntax } \\ & \text { Admiration 2(6). https://doi.org/10.46799/jsa.v2i6.260 } \\ \text { E-ISSN: } & 2722-5356 \\ \text { Published by: } & \text { Ridwan Institute }\end{array}$




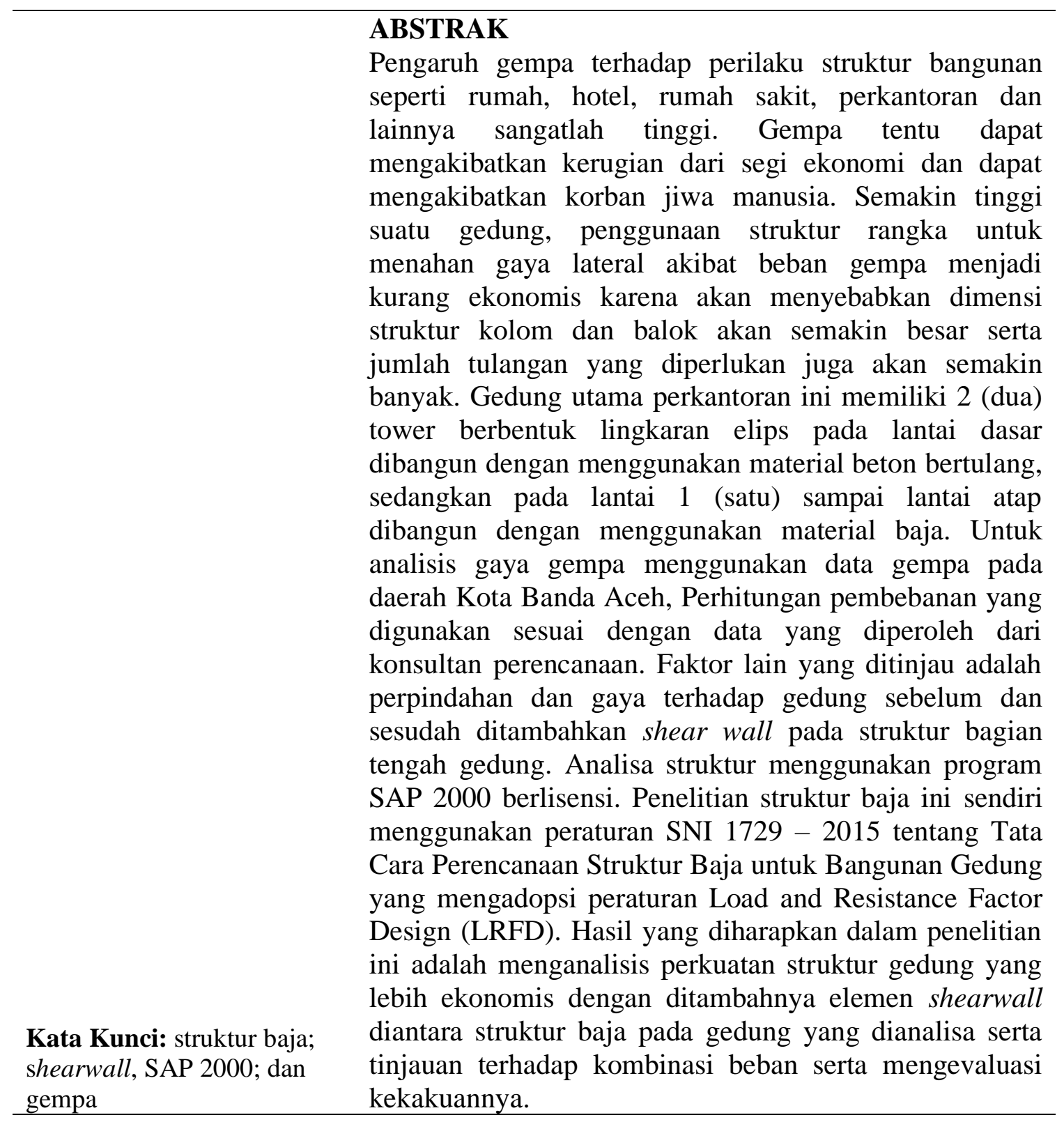

\section{Pendahuluan}

Gempa bumi merupakan suatu fenomena alam yang tidak dapat dihindari, tidak dapat diramalkan kapan terjadi dan berapa besarnya, serta akan menimbulkan kerugian baik harta maupun jiwa bagi daerah yang ditimpanya dalam waktu relatif singkat (Adrayazi, 2006). Provinsi Banda Aceh merupakan salah satu dari daerah Indonesia yang masuk ke dalam zona lima rawan gempa. Gempa dapat mengakibatkan kerusakan pada struktur sehingga struktur tersebut tidak bisa digunakan lagi. Tantangan atau permasalahan tersebut mendorong para insinyur sipil mempelajari lebih dalam lagi tentang rekayasa gempa, dimulai dari perilaku dan pengaruhnya dan dari situlah para insinyur sipil merencanakan suatu struktur pada gedung dapat meminimalisir pengaruh gempa terhadap gedung tersebut. 
Semakin tinggi suatu gedung, penggunaan struktur rangka untuk menahan gaya lateral akibat beban gempa menjadi kurang ekonomis karena akan menyebabkan dimensi struktur kolom dan balok akan semakin besar serta jumlah tulangan yang diperlukan juga akan semakin banyak. Oleh karena itu, untuk meningkatkan kekakuan dan kekuatan struktur terhadap gaya lateral dapat digunakan kombinasi antara struktur rangka dengan dinding geser. Dengan adanya hubungan yang rigid antara kolom, balok dan dinding geser akan memungkinkan terjadinya interaksi antara struktur rangka dan dinding geser secara menyeluruh pada bangunan, dimana struktur rangka dan dinding geser akan bekerja bersama-sama dalam menahan beban yang bekerja baik itu beban gravitasi maupun beban lateral (Triady et al., 2017) Gempa bumi tersebut mempunyai risiko mengakibatkan terjadinya kerusakan bangunan, oleh karena itu diperlukan struktur yang kuat untuk memikul beban struktur dan menahan gaya yang ditimbulkan oleh gempa bumi. Salah satu cara perkuatan struktur adalah dengan menggunakan shear wall.

Shear wall adalah dinding yang berfungsi sebagai pengaku yang menerus sampai ke pondasi dan merupakan dinding inti untuk memperkaku bangunan yang dirancang untuk menahan gaya geser, gaya lateral akibat gempa bumi. Dengan adanya dinding geser yang kaku pada bangunan, sebagian besar beban gempa pada bangunan bertingkat akan terserap oleh dinding tersebut.

Dalam merancang struktur bangunan bertingkat ada prinsip utama yang harus diperhatikan yaitu meningkatkan kekuatan struktur terhadap gaya lateral. Semakin tinggi bangunan semakin rawan pula bangunan tersebut dalam menahan gaya lateral, terutama gaya gempa. Salah satu solusi alternatif yang digunakan untuk meningkatkan kinerja struktur bangunan tingkat tinggi dalam mengatasi simpangan horizontal adalah dengan pemasangan dinding geser (shearwall).

Dinding geser adalah slab beton bertulang yang dipasang dalam posisi vertikal pada sisi gedung tertentu yang berfungsi menambah kekakuan struktur dan menyerap gaya geser yang besar seiring dengan semakin tingginya struktur. Fungsi dinding geser dalam suatu struktur bertingkat juga penting untuk menopang lantai pada struktur dan memastikannya tidak runtuh ketika terjadi gaya lateral akibat gempa. Ketika dinding geser ditempatkan pada lokasi-lokasi tertentu yang cocok dan strategis, dinding tersebut dapat digunakan secara ekonomis untuk menyediakan tahanan beban horizontal yang diperlukan.

Rumusan masalah yang akan dibahas adalah menganalisis struktur gedung BPJN Aceh dari lantai 2 sampai lantai atap berbahan material baja terhadap kombinasi beban dan kekakuannya, Serta membandingkan ukuran wide flange yang lebih ekonomis dan ditambahkan elemen dinding geser atau shear wall pada struktur Gedung BPJN Aceh.

Menurut (Smith et al., 1996) peraturan (codes) pembebanan mendefinisikan beban seperti beban mati, beban hidup, beban gempa, beban angin untuk perencanaan suatu struktur. Perencana harus memberikan beban yang lebih besar pada perencanaan struktur baja. Kondisi tersebut dinamakan beban nominal. Tiap-tiap beban nominal dikalikan dengan faktor beban. Faktor beban diberikan ketika analisis struktur baja agar 
didapatkan kombinasi beban yang paling kritis dan beban tersebut digunakan untuk perencanaan struktur baja. Metode ini dikenal dengan metode ultimit (batas) atau Load and Resistance Factor Design (LRFD). Kurva tegangan - regangan untuk baja mutu tinggi dapat dilihat pada Gambar 1

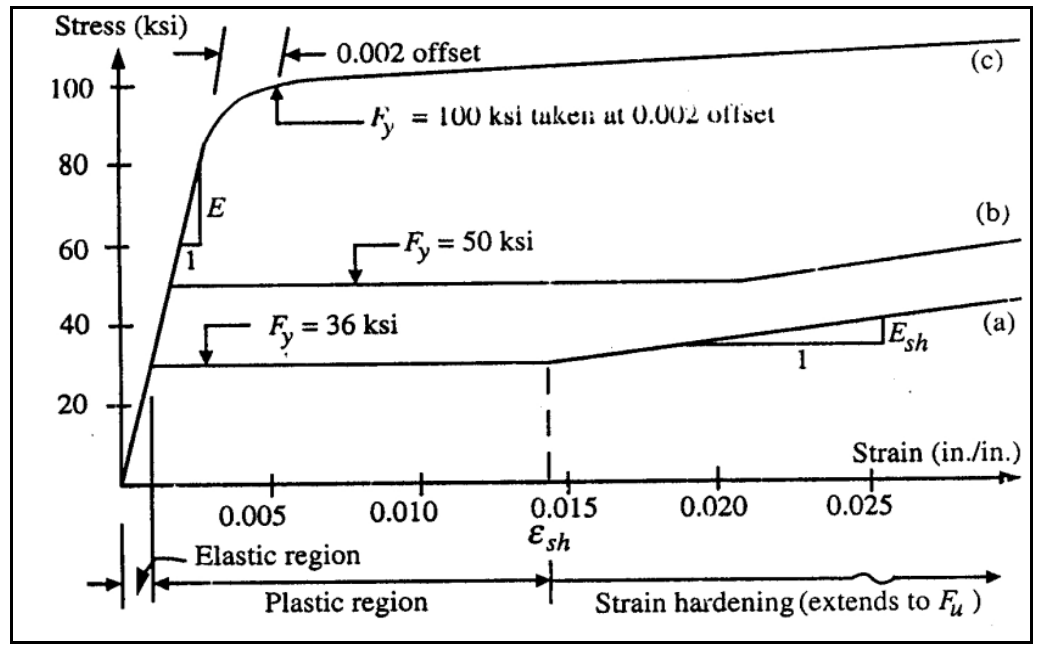

Gambar 1

Kurva tegangan - regangan baja

(Sumber: (Smith et al., 1996))

Menurut (Dewobroto, 2006) konsep perencanaan batas yang digunakan dalam peraturan baja Indonesia yaitu SNI 03-1729-2002 mengadopsi peraturan AISC-LRFD. Load and Resistance Factor Design (LRFD) adalah metode perencanaan struktur sedemikian sehingga pada saat dibebani dengan berbagai kombinasi beban terfaktor yang direncanakan, maka kondisi batasnya tidak dilampaui. Kondisi batas (limit state) adalah kondisi dimana struktur atau komponen struktur yang ada menjadi tidak fit (kondisi yang menyebabkan ketidaknyamanan atau kerusakan atau bahkan keruntuhan). Untuk setiap kondisi batas sistem struktur harus memenuhi $R_{u} \leq \varphi R_{n}$.

Menurut (Rahmania, 2018) Pengertian struktur Struktur adalah sarana untuk menyalurkan beban dalam bangunan ke dalam tanah. Fungsi struktur dalam bangunan adalah untuk melindungi suatu ruang tertentu terhadap iklim, bahayabahaya yang ditimbulkanalam dan menyalurkannya semua macam beban ke tanah. Adapun macammacam struktur sebagai berikut: Macam-macam struktur 1. Struktur Rangka 2. Struktur Dinding Geser 3. Struktur Core 4. Struktur Dinding Pemikul 5. Struktur Gantung 6. Struktur Pondasi 1. Struktur Rangka Pengertian : Dalam struktur bangunan bertingkat tinggi, struktur rangka merupakan grid persegi teratur yang terdiri dari kolom vertical dan balok horizontal yang dihubungkan di suatu bidang yang menggunakan sambungan kaku.

Elemen-Elemen Linier Dalam Merancang Struktur Bangunan Tinggi Dengan Struktur Rangka Struktur rangka merupakan suatu elemen linier yang berbentuk struktur bagian atas bangunan, dimana hal-hal yang perlu diperhatikan dalam merancang elemen linier tersebut antara lain : 1. Bidang Momen Dengan mengetahui bidang momen pada 
balok dan balok portal maka arsitek dapat merancang system struktur yang efisien dalam ukuran balok serta mengetahui di bagian mana dari balok yang memerlukan tulangan terbanyak. Tinggi balok sama dengan seperduabelah bentang. $\mathrm{h}=1 / 12 \mathrm{xl} h=$ lebar atau tinggi balok $\mathrm{L}=$ lebar bentang 2. Struktur portal Ada berbagai macam struktur portal yang digunakan dalam merancang struktur bangunan, antara lain : a. Portal tunggal (1Bentang) b. portal bertingkat (1bentang) c. portal majemuk ( 2 bentang).

Shear Wall adalah jenis struktur dinding yang berbentuk beton bertulang yang biasanya dirancang untuk menahan geser, gaya lateral akibat gempa bumi. Dengan adanya Shear Wall / dinding geser yang kaku pada bangunan, sebagian besar beban gempa akan terserap oleh dinding geser tersebut.

Dinding geser biasanya ditempatkan di luar, di dalam ataupun berupa inti yang memuat ruang lift atau tangga. Perencanaan dinding geser yang baik tidak terlepas dari pemilihan bentuk dinding, lokasi penempatannya pada denah serta bentuk ragam keruntuhannya.

Dinding geser pada dasarnya dapat dibagi menjadi system terbuka dan sistem tertutup. Sistem terbuka terdiri dari unsur linear tunggal atau gabungan unsur yang tidak lengkap melingkupi ruang geometris, seperti bentuk L, X, V, Y, T, H. Sebaliknya sistem tertutup melingkupi ruang geometris seperti bentuk persegi, segitiga, persegi panjang dan bulat. Bentuk dan penempatan dinding geser sendiri mempunyai akibat yang besar terhadap struktur apabila dibebani secara lateral (Wolfgang, 1977).

Untuk letak pemasangan dinding geser yang biasa di gunakan dilapangan dapat di lihat dari Gambar 2.2.

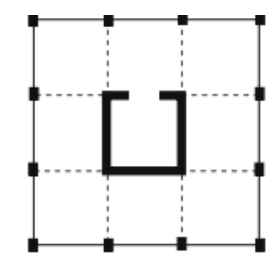

(a) Tipe Tube

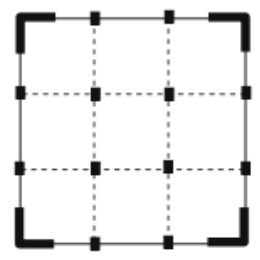

(c) Tipe L-shape

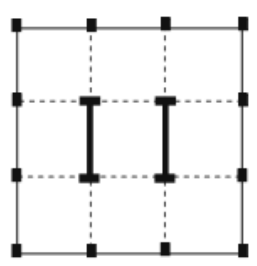

(e) Tipe I-shape

Gambar 2

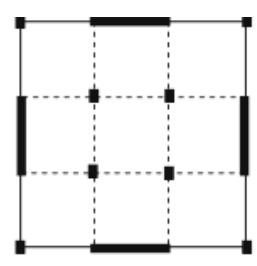

(b) Tipe Rectangle

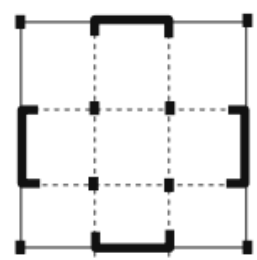

(d) Tipe C-shape

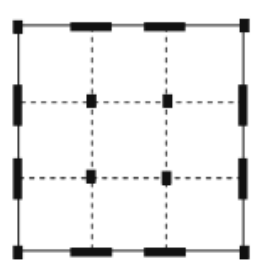

(f) Tipe Coupled SW

\section{Beberapa Tipe Dinding Geser di Lapangan}

(Sumber: (Nur et al., 2011) 
Efisiensi Penggunaan Dimensi Balok Wide Flange (WF) terhadap Kekakuan Struktur Gedung BPJN Aceh dengan Penambahan Elemen Shear Wall

\section{Metode Penelitian}

1. Data Struktur Gedung

Untuk membuat model tiga dimensi gedung dalam penelitian ini maka dibutuhkan data-data dimensi keseluruhan dari komponen struktur gedung. Data tersebut didapatkan dari gambar rencana gedung. Model tiga dimensi dapat dilihat pada Gambar 4. Data struktur Gedung Perkantoran dapat dilihat pada Tabel 1

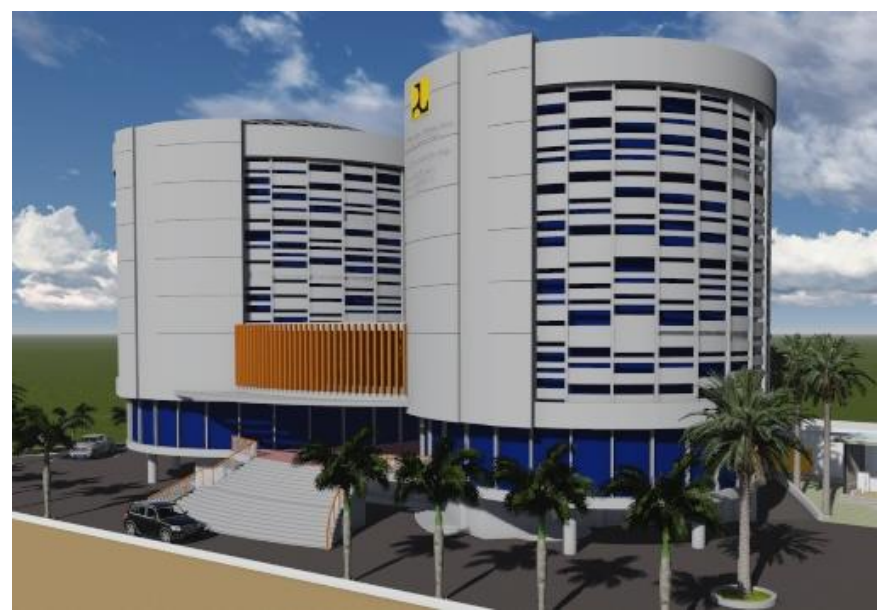

Gambar 3

Gedung Perkantoran BPJN Aceh

Tabel 1

Data Struktur Gedung

\begin{tabular}{ccc}
\hline No. & Kriteria & Studi Kasus \\
\hline 1 & Sistem Struktur & Sistem tunggal/Portal \\
\hline 2 & Fungsi Gedung & Perkantoran \\
\hline 3 & Jumlah Lantai & 6 \\
\hline 4 & Tinggi Total & $24 \mathrm{~m}$ \\
\hline 5 & Lokasi & Banda Aceh \\
\hline 6 & Jenis Tanah & Tanah Sedang \\
\hline 7 & Material Struktur & Beton Bertulang dan Baja WF \\
\hline
\end{tabular}

2. Data Material

Struktur gedung didesain menggunakan bahan beton bertulang dengan mutu dan persyaratan sesuai dengan SNI 03-2847-2013 dan PPURG 1987 sebagai berikut:

Kuat tekan beton $=\mathrm{K} 300$ (balok dan lantai)

Tegangan leleh tulangan $=400 \mathrm{MPa}$

Beban yang direncanakan terdiri dari beban mati, beban hidup dan beban gempa. Untuk beban mati dan beban hidup sesuai dengan persyaratan PPURG 1987 dan SNI 1727-2013. Beban mati pada gedung dapat dilihat pada Tabel 2. Beban hidup pada gedung dapat dilihat pada Tabel 2. 
Tabel 2

Beban Mati pada Gedung

\begin{tabular}{ccc}
\hline No. & Kriteria & $\begin{array}{c}\text { Berat } \\
(\mathbf{K N} / \mathbf{m 3})\end{array}$ \\
\hline 1 & Beton bertulang & 24 \\
\hline 2 & Lapisan aspal & 14 \\
\hline 3 & Curtain wall kaca & 0,6 \\
\hline 4 & Langit- langit dan penggantung & 0,2 \\
\hline 5 & Finishing lantai & 22 \\
\hline 6 & Marmer, granit per cm tebal & 0,24 \\
\hline 7 & Instalasi plumbing & 0,25 \\
\hline
\end{tabular}

Sumber: PPURG 1987

Tabel 3

Beban Mati pada Gedung

\begin{tabular}{ccc}
\hline No. & Jenis Beban & $\begin{array}{c}\text { Berat } \\
(\mathbf{K N} / \mathbf{m} \mathbf{3})\end{array}$ \\
\hline 1 & Ruang Kerja Pegawai & 2,87 \\
\hline 2 & Ruang Kerja Kepala & 1,92 \\
\hline 3 & Koridor & 3,83 \\
\hline 4 & Ruang Pertemuan & 4,79 \\
\hline 5 & Atap datar & 0,96 \\
\hline 6 & Atap untuk dudukan tampungan air & 4,79 \\
\hline 7 & Helipad & 2,87 \\
\hline
\end{tabular}

Sumber: SNI 1726-2012

Beban gempa menggunakan analisis riwayat waktu beban gempa. Riwayat waktu yang digunakan dalam analisis menggunakan akselerogram El Centro dengan percepatan puncak $0,319 \mathrm{~g}$ dan durasi selama 12 detik seperti yang ada pada Gambar 5.

Riwayat waktu gempa harus disesuaikan terlebih dahulu dengan percepatan tanah puncak lokasi yang ditinjau. Berdasarkan SNI 1726-2012 percepatan tanah puncak Banda Aceh didapatkan dari Gambar 5

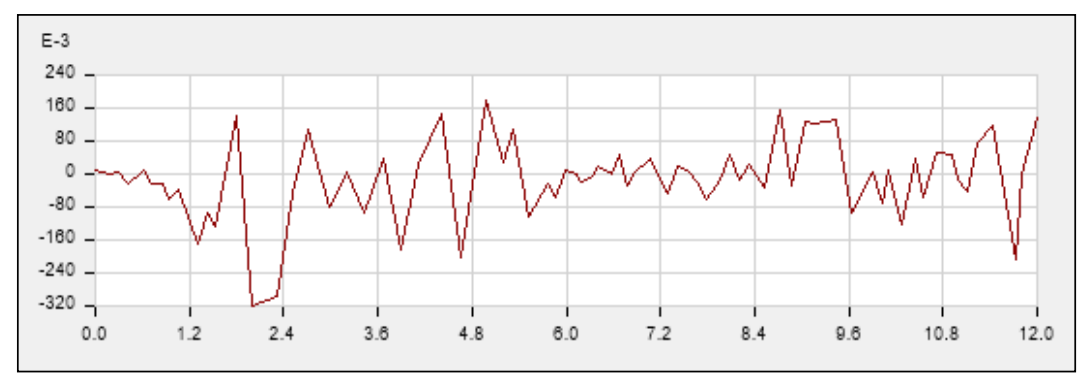

Gambar 5

Gempa El Centro 


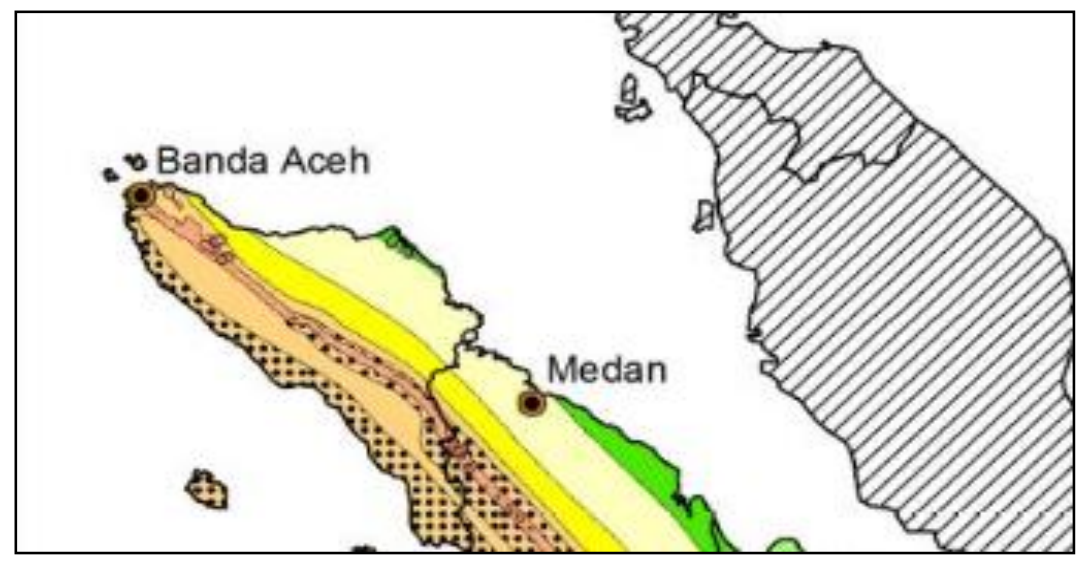

Gambar 6

Kondisi PGA Banda Aceh

Berdasarkan Gambar 6 nilai PGA Banda Aceh digunakan sebesar 0,214 g. Berdasarkan SNI 1726-2012 untuk kelas situs SD dan nilai PGA 0,214 g maka didapatkan nilai FPGA sebesar 1,371. Sehingga untuk mendapat PGA $_{M}$ digunakan persamaan.

$\mathrm{PGA}_{\mathrm{M}}=\mathrm{FPGA} \times \mathrm{PGA}$

$\mathrm{PGA}_{\mathrm{M}}=1,371 \times 0,214$

$\mathrm{PGA}_{\mathrm{M}}=0,293 \mathrm{~g}$

\section{Pemodelan Gedung}

Gedung dimodelkan dan dianalisis menggunakan program berbasis elemen hingga seperti pada Gambar 6. Gedung yang dimodelkan adalah gedung tanpa shear wall, gedung existing, dan gedung modifikasi. Model modifikasi adalah model dengan penempatan posisi shear wall yang berbeda dari existing berdasarkan parameter eksentrisitas. Denah pemodelan gedung dapat dilihat pada Gambar 7 sampai Gambar 9.

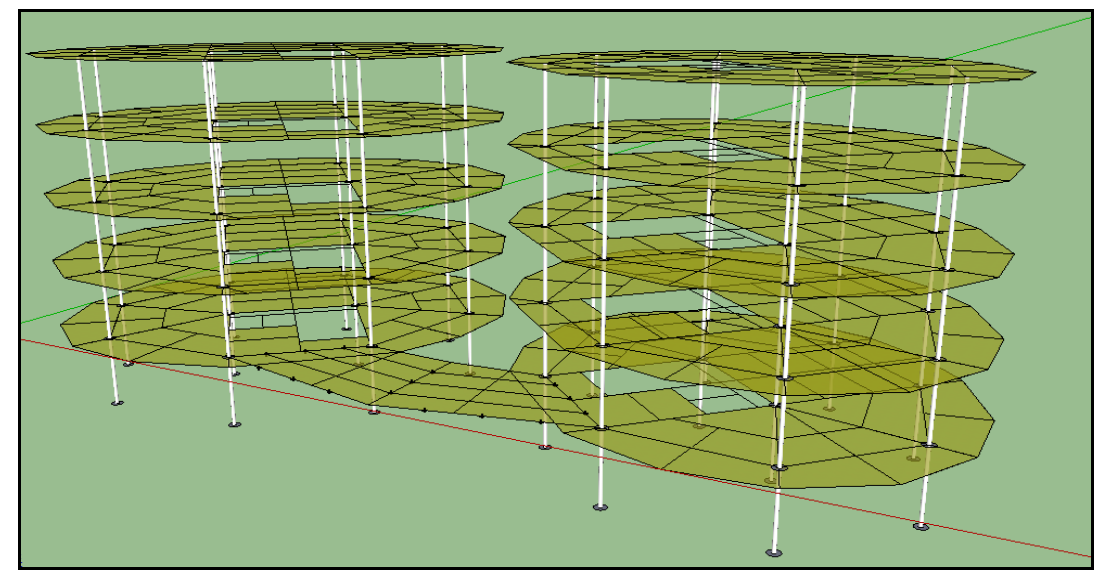

Gambar 7

Pemodelan 3D non Shearwall 


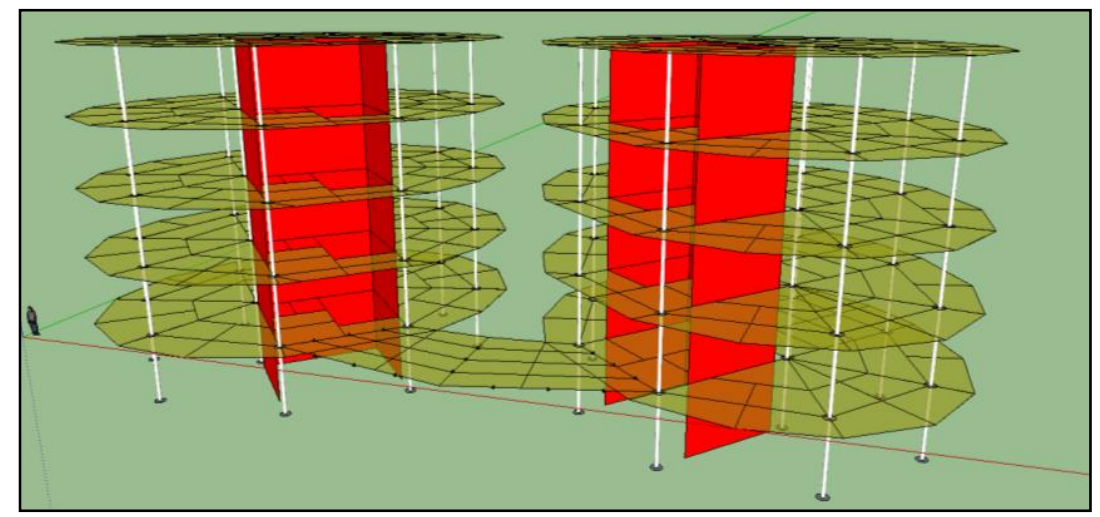

\section{Gambar 8}

Pemodelan 3D shearwall

4. Tahapan Analisis

Analisis dilakukan dengan cara memodelkan struktur gedung ke dalam program SAP 2000 hingga berupa balok, kolom, pelat lantai dan shear wall sesuai data yang digunakan. Setelah pemodelan selesai maka selanjutnya dilakukan analisis dengan menggunakan beban gempa riwayat waktu sehingga didapatkan parameter periode fundamental dan respons struktur. Berikut penjelasan tahapan analisis dengan bantuan program SAP 2000:

a. Tahapan yang pertama kali dilakukan adalah persiapan literatur yang sesuai dengan topik pembahasan yang akan dianalisa.

b. Memodelkan struktur Gedung Balai Pelaksanaan Jalan Nasional-I Banda Aceh dengan menggunakan software SAP 2000 dan data Struktur yang digunakan sesuai dengan data-data yang didapatkan dari perencanaan gedung tersebut.

c. Menganilisis kombinasi-kombinasi pembebanan yang digunakan pada program sesuai SNI 1726-2013;

d. Setelah analisis pembebanan, kemudian struktur dianalisis untuk mengetahui gaya dalam, dan perpindahan struktur sesudah ditambahkan shear wall pada struktur tengah gedung dengan struktur tanpa shear wall. Selanjutnya akan dibandingkan respon struktur sesudah ditambahkan shear wall dengan struktur tanpa shear wall.

Sistem struktur pada bangunan ini menggunakan PIPA SCH20 Ø24" t=0.5" untuk kolom induk profil WF1 60x20 untuk balok utama, profil WF2 40x20 dan WF3 $(35 \times 17,5)$ untuk balok yang dipakai pada struktur lantai 2 sedangkan WF4 (30x15) digunakan pada lantai 3 sampai lantai atap. Hasil output untuk salah satu kolom SCH20 yang dihasilkan oleh SAP untuk beban ultimit dan tahanan pada struktur Non shearwall dan struktur shearwall dapat dilihat pada Tabel 4.1 
Tabel 4

Rasio PU dan ФPN pada Kolom SCH20 Tower 1 Struktur Non Shearwall

\begin{tabular}{cccccc}
\hline Lantai & $\begin{array}{c}\text { No. } \\
\text { Frame }\end{array}$ & Profil & Rasio & $\begin{array}{c}\text { Beban Ultimit }\left(\boldsymbol{P}_{\boldsymbol{u}}\right) \\
\text { kg }\end{array}$ & $\begin{array}{c}\text { Beban Tahanan }\left(\boldsymbol{\Phi} \boldsymbol{P}_{\boldsymbol{n}}\right) \\
\text { Kg }\end{array}$ \\
\hline 1 & 59 & SCH 20 & 4.396 & 163009 & 37126 \\
\hline 2 & 177 & SCH 20 & 0.437 & 129667 & 300608 \\
\hline 3 & 515 & SCH 20 & 0.274 & 98238 & 362082 \\
\hline 4 & 639 & SCH 20 & 0.098 & 66890 & 362082 \\
\hline 5 & 1075 & SCH 20 & 0.079 & 35489 & 400254 \\
\hline
\end{tabular}

Sumber: SAP 2000 Analisis

Tabel 5

Rasio $P_{u}$ dan $\Phi P_{n}$ pada Kolom SCH20 Tower 1 Struktur Shearwall

\begin{tabular}{cccccc}
\hline Lantai & $\begin{array}{c}\text { No. } \\
\text { Frame }\end{array}$ & Profil & $\begin{array}{c}\text { Rasi } \\
\mathbf{0}\end{array}$ & $\begin{array}{c}\text { Beban Ultimit }\left(\boldsymbol{P}_{\boldsymbol{u}}\right) \\
\mathbf{K g}\end{array}$ & $\begin{array}{c}\text { Beban Tahanan }\left(\boldsymbol{\Phi} \boldsymbol{P}_{\boldsymbol{n}}\right) \\
\mathbf{K g}\end{array}$ \\
\hline 1 & 59 & SCH20 & 0,456 & 180046 & 402801 \\
\hline 2 & 733 & SCH20 & 0,331 & 127515 & 404032 \\
\hline 3 & 617 & SCH20 & 0,224 & 88019 & 406135 \\
\hline 4 & 957 & SCH20 & 0,073 & 55194 & 406135 \\
\hline 5 & 1075 & SCH20 & 0,044 & 26489 & 409677 \\
\hline
\end{tabular}

Sumber: SAP 2000 Analisis

Dari tabel diatas dapat dilihat bahwa struktur non shearwall pada penampang kolom SCH20 pada lantai 1 sampai lantai 5 tersebut memiliki rasio lebih besar dibandingkan rasio yang telah ditambahkan struktur shearwall.

Perbandingan momen lentur dan gaya geser antara Struktur Non Shearwall dan Struktur Shearwall dapat dilihat pada gambar 9 grafik garis dibawah ini.

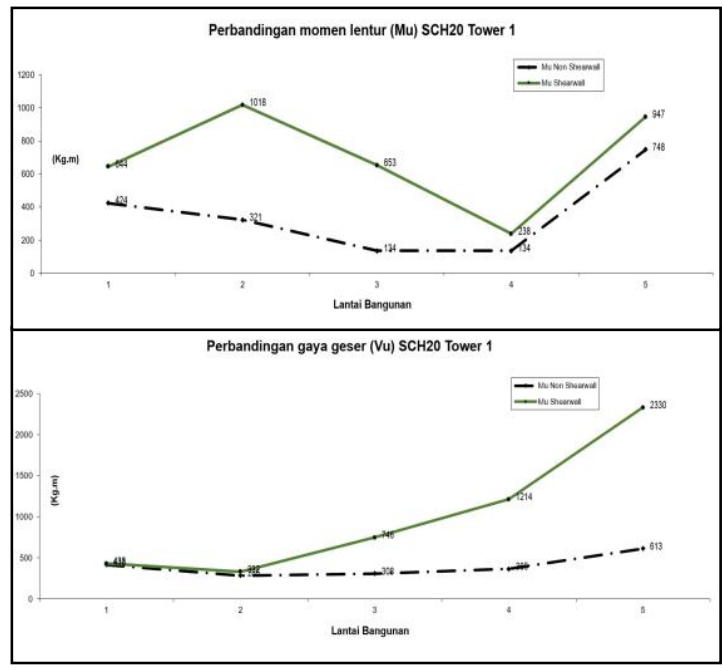

Gambar 9

Perbandingan momen lentur dan geser antara Struktur non shearwall dan Struktur Shearwall pada kolom SCH20 Tower 1 sumber : SAP 2000 Analisis

Pada grafik perbandingan diatas dapat kita simpulkan bahwa momen lentur pada struktur non shearwall pada lantai 1 sampai lantai 5 lebih besar dibandingkan struktur shearwall, pada lantai 1 momen lentur non shearwall lebih kecil lalu meningkat pada 
lantai 3 dan 4. Non shearwall memiliki ketidakstabilan terhadap momen geser, sedangkan pada struktur Shearwall memiliki kestabilan terhadap momen lentur dan momen geser, oleh karena itu stuktur bangunan ini sangat baik apabila ditambahkan shearwall.

\section{Hasil dan Pembahasan}

Kapasitas momen tahanan lentur untuk struktur Shearwall cukup bagus. Rasio antara Momen ultimit dengan momen tahanan berkisar antara 0,026-0,226. Apabila rasio tersebut semakin mendekati angka 1 berarti struktur tersebut semakin kritis (tidak aman). Sebaliknya, semakin mendekati angka 0 berarti batang tersebut semakin aman. Pada penelitian kembali ini rasio yang timbul adalah mendekati angka 0, artinya kapasitas momen tahanan yang diberikan oleh stuktur Shearwall cukup bagus dalam menahan beban lentur. Momen tahanan lentur dan geser pada Shearwall menjadi lebih besar serta menjadikan sistem ini lebih kaku dan lebih kokoh.

\section{Kesimpulan}

Pemasangan dinding geser /shearwall pada struktur gedung tersebut dengan bentuk struktur seperti yang telah dibahas dapat meningkatkan kekakuan struktur. Kapasitas momen tahanan lentur pada balok untuk shearwall cukup bagus. Rasio antara momen ultimit dengan momen tahanan berkisar antara 0,01 - 0,08. Apabila rasio tersebut semakin mendekati angka 1 berarti batang tersebut semakin kritis (tidak aman). Sebaliknya, semakin mendekati angka 0 berarti batang tersebut semakin aman. Pada penelitian kembali ini rasio yang timbul adalah mendekati angka 0, artinya kapasitas momen tahanan yang diberikan oleh balok pada struktur shearwall cukup bagus dalam menahan beban lentur. Untuk dimensi balok yang sudah diperkecil pada penelitian ini ternyata menghasilkan momen tahanan lentur yang besar. Momen ultimit pada shearwall lebih kecil karena sistem ini lebih kaku dan lebih kokoh. Hal ini karena adanya pengekang lateral yaitu dinding geser (shearwall). 
Efisiensi Penggunaan Dimensi Balok Wide Flange (WF) terhadap Kekakuan Struktur Gedung BPJN Aceh dengan Penambahan Elemen Shear Wall

\section{BIBLIOGRAFI}

Adrayazi, E. (2006). Disain Ulang Struktur Dinding Geser Asrama Mahasiswa Unand. Tugas Akhir Strata, 1 Google Scholar.

Dewobroto, W. (2006). Evaluasi Kinerja Bangunan Baja Tahan Gempa dengan SAP2000. Jurnal Teknik Sipil, 3(1), 7-24.Google Scholar

Nur, E., Biemond, B. J., Otten, H., Brandjes, D. P., Schnog, J. B., \& Group, C. S. (2011). Oxidative stress in sickle cell disease; pathophysiology and potential implications for disease management. American Journal of Hematology, 86(6), 484-489.Google Scholar

Rahmania, A. S. (2018). Pengaruh Kombinasi Core Stability Exercise Dan Jalan Tandem Terhadap Penurunan Resiko Jatuh Pada Lansia Di Posyandu Lansia Junrejo Kota Batu. University of Muhammadiyah Malang. Google Scholar

Smith, G. D., Yoon, D. Y., Jaffe, R. L., Colby, R. H., Krishnamoorti, R., \& Fetters, L. J. (1996). Conformations and structures of poly (oxyethylene) melts from molecular dynamics simulations and small-angle neutron scattering experiments. Macromolecules, 29(10), 3462-3469.Google Scholar

Triady, F., Makmur, T., \& Irwan, I. (2017). Prospek Pengolahan Daun Nipah Sebagai Bahan Baku Pembungkus Tembakau di Desa Keude Jrat Manyang Kecamatan Tanah Pasir Kabupaten Aceh Utara. Jurnal Ilmiah Mahasiswa Pertanian, 2(1), 116-126.Google Scholar

Wolfgang, S. (1977). High Rise Building Structures. New York: John Wiley \& Sons.Google Scholar

Copyright holder :

Fakhrul Razi, Yulia Hayati, Teuku Budi Aulia (2021)

First publication right:

Jurnal Syntax Admiration

This article is licensed under:

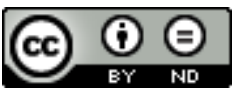

